\title{
Lighting the fire for media freedom
}

'In Samoa, the media can be described as a tree that has no shadow. It offers neither shelter nor hope. It can be described as a flower that blooms but then quickly withers, as if afraid of the sunlight. Others see it as a confused animal; a sick dog which barks but won't bite because it is afraid.'

\section{By SAVEA SANO MALIFA}

THERE IS A darker side to press freedom and human rights. It is the lack of that freedom and the violation of those rights. Press freedom is the soul of a nation, without which that nation withers and dies. We see this happening in countries around the world where press freedom is denied. There are wars, bloodshed, famine, poverty and suffering.

My experience cannot be compared to that which other colleagues working under more volatile regimes go through. Some of them have been killed for speaking their mind. But together we are inspired by the same principle and in our struggle, we aim for the same goal.

Needless to say, press freedom and human rights must be protected at any cost because they sustain natural democracy. Freedom is the spirit that strengthens the work of all practising journalists. A vigilant press is vital for the survival of democracy. It is essential for the survival of mankind because without this freedom, there can be no democracy. This freedom is needed even more in small countries in the Pacific because our governments are young, and our economies are fragile. But because some of our countries are run by unprincipled men with one-track vision, the temptation to get rich quickly is overpowering. To those men power is irresistible. Many of them will do anything to stay in power. And that is why there is a concerted effort to do away with press freedom.

The role of the free press as the watchdog of public interest is vital because 92 PACIFIC JOURNALISM REVIEW 5:1 1999 


\section{SAMOA}

such a role keeps the public informed and governments straight and honest.

In Samoa, the media can be described as a tree that has no shadow. It offers neither shelter nor hope. It can be described as a flower that blooms but then quickly withers, as if afraid of the sunlight. Others see it as a confused animal; a sick dog which barks but won't bite because it is afraid.

The publicly-owned media in Samoa is tightly controlled by the government. At the same time, the private one is succumbing to pressure, preferring to compromise to protect whatever share it has in a competitive and small market. It feels it is justified in doing this in a country ravaged by a high cost of living, high import duties and taxes, intimidation and corruption.

At this stage in the political development of Samoa, press freedom is in danger of being taken away by force. There is a government campaign aimed at thwarting people's right to criticise and question. It involves spending huge amounts of public funds and intimidation to silence critics.

Press freedom in Samoa has often come under fierce assault from government leaders who file defamation claims aimed at crippling press freedom. I am ashamed to say that at the time when the world is about to celebrate the 50th anniversary of the Declaration of Human Rights, the Samoan government is intent on suppressing those rights. Although the press has many sympathisers, only a handful are prepared to speak out publicly. Many people write letters to the editors criticising the Government. But because they are so afraid of being victimised, they do not write their real names. They know that those who openly criticise the Government get punished, one way or another. For instance, Samoa's Chief Auditor was sacked for exposing corruption in government in a 94-page report released in June 1994.

The Office of the Chief Auditor has since been weakened, with the incumbent's term of office reduced to three years when previously chief auditors can serve until they are 60 . Now who there would dare criticise the Government?

Samoa is one of the few countries practising double standards in defamation cases. Apart from civil defamation laws, the country also has criminal libel laws. And another law, the Printers and Newspapers Act 1992 requires editors to reveal the names of their sources. The thrust of this law is to discourage people leaking information to the press. It worked in a way because sources stopped calling. But we still get information leaked to us through other means, like in an envelope, either sent in by mail or thrust in under the door at night.

My government's determination to cover up corruption was highlighted in PACIFIC JOURNALISM REVIEW 5:1 199893 


\section{SAVEA SANO MALIFA}

a letter by an American tourist who compared our Government to Richard Nixon's administration. He said: "Nixon's administration had done many good things for the country, but they were overshadowed by the corruption surrounding the Watergate scandal. It would be a shame if all that will be remembered of the Samoan PM's tenure of office will be the passport scandal, the Controller and Chief Auditor's report about corruption, and the changing of the Constitution to reduce the strength of his office."

I say that a free press is essential for the survival of democracy. The framers of Samoa's Constitution were obviously aware that governments would not always remain honest guardians of public properties, knowing that absolute power corrupts absolutely. They insisted therefore that there should be a free press to constantly check on what governments were up to.

There's a general agreement that publishers of newspapers must take the consequences of their own decisions. But at the same time they must be free to publish reports of public interest.

In Samoa, the Government owns a radio station, the only television station, and a newspaper. TV Samoa was set up about three years ago. Up to now it has never allowed air time to the Opposition. Our Prime Minister told the Parliament that the Opposition would not be allowed on television because its leader would use the opportunity to air his "manipulative" opinions. TV Samoa is therefore a Government network publicising government ministers making speeches at official functions, festivals, dedications, handling-over of public-funded projects in villages, and what not.

The private media is made up of one daily newspaper, two weeklies and three radio stations. Newspapers printed in New Zealand are also distributed in Samoa.

The private media is an irritating thorn in the side of the Government. For example, it was the private press that revealed how the Government-owned Polynesian Airlines was dragging the country into near-bankruptcy, with accumulated losses that were raising the national debt over $\$ 400$ million compared to $\$ 30$ million 10 years ago.

It was the private press that revealed the case of a roading contract, which a cabinet minister won and charged \$US47,000 a mile for 26 miles when all the equipment, vehicles and materials used were either publicly owned or funded.

It was also the private press that reported how a cabinet minister sold an WS $\$ 8000$ generator to Public Power Authority for $\$ 89,000$. 


\section{In Samoa, the}

Government doesn't

like the words

accountability and

transparency ... This

campaign to curb

\section{dissent and free}

speech in our country

has got to stop.

It was also the private press that revealed how Samoan passports were being sold to foreigners in the United States, Hong Kong, Tonga, American Samoa and even in Samoa itself.

Today, there is a campaign in Samoa to impede the free flow of information and free speech. It is being done without regard to public concern. When members of the public can no longer form opinions of their own, and (even) indulge in a bit of humour, society is no longer a safe place to be.

In Samoa, the Government does not like the words accountability and transparency. This is why it sacked the Chief Auditor and threatened to refuse business licences to news organisations which "stir up trouble."

This campaign to curb dissent and free speech in our country has got to stop. One day when our Government leaders accept the free press for what it is - as a campaigner for fairness and honest governments - then democracy will be assured, and life in Samoa truly envied by the rest of the world.

Now I come to the most sensitive part, our Government's campaign to silence my newspaper - the Samoa Observer. It all started in the early 1980s when the Prime Minister sued us for $\$ 250,000$, claiming defamation. Five years later, his case was quietly withdrawn.

The next writ came from the Minister for Public Works who walked into the Observer office one morning and threatened to kill me, as editor, and my family for a report we published about him and some cattle. Two minister's brothers attacked the editor in Apia. We have been sued for $\$ 200,000$. The case is pending.

The next writ came from the Minister of Finance, who is seeking $\$ 250,000$ in damages, claiming he had been defamed in a report we published about bribes for voters. That case, too, has been withdrawn. It was at about that time the Printers and Publishers Act was pushed through Parliament and quickly became law.

In April 1994, the newspaper printing plant was destroyed by fire. Police 


\section{SAVEA SANO MALIFA}

described the fire as "suspicious". This was also the opinion of insurance investigators who said they discovered several "hot spots" in the debris. The investigation is continuing.

After the fire, came the advertisement ban in which all Government departments and corporations were ordered by cabinet not to advertise in the private press, especially the Observer. They were to advertise only in the Government-owned media.

Then in January last year, light passenger aircraft operated by the Government-owned Polynesian Airlines crashed on a mountain in Samoa killing two passengers and the pilot. A reporter and a photographer from the Observer flew in by helicopter and were the first to get to the crash site. They found two survivors, the co-pilot and a young girl. But their coverage of the crash offended the airline which sued the Observer for $\$ 1.1$ million. The matter was settled out to court with the Observer only having pay for its legal fees.

In a landmark case, the Prime Minister has brought criminal libel charges against the Observer, the first time such a case has been brought before the courts in Samoa under the Crimes Ordinance Act.

This case stemmed from a satirical letter to the editor sent by a Samoan living in New Zealand and published in the Samoan language. Styled along the format of the Bible's Book of Revelations, the letter was aimed at invoking humour. The Prime Minister, however thought otherwise and said the letter has damaged his reputation.

I am reminded of Erica Jong's book Fear of Flying. In the book she said: "If we can ban whatever offends any group in our diverse society, we will soon have no art, no culture, no humour, no satire."

Again in 1997, the Prime Minister sued the Observer for $\$ 400,000$ claiming he had been defamed in the coverage of his family's business activities. The case went to court. As the trial was coming to an end, the Government announced that $\$ 783,000$ has been allocated for the Prime Minister's legal fees. To justify that he said that from then on the public would pay for the legal fees in defamation cases brought about by cabinet ministers, the head of state, members of the council of deputies, and other Government leaders. That, the Government said, should discourage the Press from defaming public officials.

The Observer lost the case. But there was at least a victory for press freedom. The judge ruled that the Observer was "successful in the principle legal argument of the case, namely that ... qualified privilege should apply to Samoa as a proper development of the common law in the interests of freedom 96 PACIFIC JOURNALISM REVIEW 5:1 1999 
of speech and expression in political discussion, without removing the balance needed to prevent defamation."

He then awarded damages of $\$ 50,000$ against the Observer. Soon after the trial, the Prime Minister's lawyers submitted their own costs of $\$ 500,000$ to be paid by the Observer, without any mention of the $\$ 783,000$ in public funds made available for that purpose. In the end, the judge settled costs at $\$ 75,000$. By then, the paper has had to pay some $\$ 350,000$ in legal fees.

While I'm writing this, I am being served with a notice from the Prime Minister's lawyers giving me seven days to pay up $\$ 125,000$ “in final judgement and costs", or bankruptcy proceedings will be served against me and the newspaper.

I tell you, there's never a dull moment in the fight for press freedom in Samoa. In fact, the fight never ends.

Savea Sano Malifa is the publisher and editor of the Samoa Observer, the country's only daily newspaper. In October 1998, he received the Lord Astor Award, the Commonwealth's most prestigious press freedom award, at the Commonwealth Press Union conference in Kuala Lumpur. These are excerpts from his speech at the conference. 